\section{WPSA Annual Meeting and Call for Nominations}

$\mathrm{W}$ PSA President Manuel Avalos and Program Chair Peregrine Schwartz-Shea are planning the 2012 Annual Meeting of the Western Political Science Association, scheduled for March 22-24, 2012, at the Marriott Waterfront in Portland, Oregon. We hope you will participate in the program. Information regarding the meeting can be found on the WPSA website, http:// wpsanet.org. Please note that the deadline for submission of participation forms is September 18, 2012. The forms will be available in early June for submission.

Additionally, the WPSA Nominations Committee requests that nominations be submitted for WPSA officer positions. Descriptions of these positions are as follows:

- Vice President: Serves as Program Chair 2013-14 for the March 2014 annual meeting in Seattle, Washington, and serves subsequently as Association President 2014-15.

- Executive Council Members: Four members: two from Region A (California); one from Region B (Arizona, Hawaii, Nevada, New Mexico, Texas, and Utah); and one from Region C (Alaska, Colorado, Idaho, Montana, Oregon, Washington, Wyoming, British Columbia, Alberta, and Saskatchewan). Terms will be for three years, March 2013-March 2016

Nominations and self-nominations are welcome. Each should be accompanied by (1) a written indication from the individual that $s /$ he is willing to serve; (2) a statement in support of the nominee, including details of previous WPSA activities; and (3) a copy of the nominee's recent vita. We encourage nominations of women and members of ethnic minorities (including women of color) and nominations that help achieve a balance of large and small schools, areas of specialization, and regions in WPSA governance.

The WPSA Bylaws specify that nomi- nees who are not residents in the western region "shall be assigned randomly by the Committee on Nominations to one of the three regional groupings."

Nominations should be sent before June 30, 2011, to: Professor Valerie Martinez- Ebers, University of North Texas, valmartinez@unt.edu.

\section{New APSA Related Group on Disasters}

\begin{abstract}
- nterested in disasters, crisis, and catastrophe? Did you follow the social and _ political consequences of the March 2011 Tohoku earthquake off the coast Japan with great interest? Would you like to be able to create more synergy among social scientists working on issues of recovery and resilience? Daniel P. Aldrich is working to create a new related group within the APSA framework, which is tentatively titled "Disasters and Crisis" and requires 50 electronic signatures by the summer to do so. Please contact him directly at daniel. aldrich@gmail.com to express your interest in joining the group.
\end{abstract}

\section{New IPSA}

Research Committee 23 on Elections, Citizens and Parties

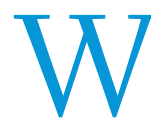

e are delighted to announce that the International Political Science Association has just approved the establishment of a new Research Committee 23 on Elections, Citizens and Parties (IPSA-ECP). This com- mittee will replace IPSA's former RC 34 (Comparative Representation and Electoral Systems and is designed to cover the interests of the old committee, as well as broadening and updating the focus.

The new network will be launched at a special one-day pre-IPSA Workshop on the Challenges of Electoral Integrity in Madrid on July 7, 2012. We will also organize two regular general panels covering any topics about elections, citizens, and parties at the IPSA Congress in Madrid from July 8-10, 2012. Proposals are warmly welcomed, and the deadline for submissions is July 1 , 2011.

We are also asking for your support to expand membership. There are no costs to joining for the first year, and after July 2012, there will be a modest subscription fee to subsidize activities. Interested parties should go to http://www.ipsa-ecp.com to add contact details to join; we would also appreciate if you could spread the word and encourage membership among your research networks.

In a world rapidly moving towards elections as the main channel of political legitimacy for regimes worldwide, where the study of elections and parties is now truly global, the aim to is make sure that IPSA is at the forefront of scholarly research and scientific inquiry on elections, citizens and parties. For more information, please see http://www. ipsa-ecp.com.

\section{IPSA Work-} shop on the Challenges of Electoral Integrity

T he IPSA Research Committee 23 on Elections, Citizens and Parties (IPSA-ECP) is organizing a special one-day workshop on the "Challenges of Electoral Integrity," which will be held in Madrid on Saturday July 7, 2012, immediately prior to the IPSA World Congress.

Lack of electoral integrity is a major chal- 
lenge facing the world. This includes flaws in the conduct of elections, raising issues of transparency, accountability, accuracy, and ethical standards. Problems of integrity can influence all stages of the electoral process, from voting procedures, boundary delimitation, voter education and registration, party/ candidate registration, campaigns, media, financing, voting, and vote counting to the declaration of the results. A growing body of research by scholars and policy analysts is starting to conceptualize the notion of ethical standards of electoral integrity and to examine techniques commonly used to manipulate electoral processes. Little is known, however, about the consequences of these practices for citizen activism and voting behavior, for feelings of political legitimacy, and thus for democracy.

The workshop is cosponsored by International IDEA, $\mathrm{RC}_{17}$ Comparative Public Opinion, and the Comparative Study of Electoral Systems (CSES).

Information about the workshop theme is available at http://www.IPSA-ECP.com.

\section{Institute for Constitutional History Robert H. Smith Seminar}

T he Institute for Constitutional History, the nation's premier institute dedicated to ensuring that future generations of Americans understand the substance and historical development of the Y.S. Constitution, introduces the Robert H. Smith Seminar for fall 2011. This seminar will examine the ways in which the Constitution and constitutional law have drawn upon international ideas, incorporated international law into our domestic legal order, and responded to international legal/political issues. These engagements and entanglements with the larger world have played a widely underappreciated role in the making and the development of constitutional law. Class discussions will also include occasional international comparisons. The seminar will proceed by case studies, including the Revolution and the eighteenth-century Constitution, slavery and the Constitution, the Civil War, the War of 1898 and imperialism, and the constitutional issues raised by the League of Nations and the United Nations. Readings will include both legal texts and relevant general historical texts, as well as relevant historiography.

The seminar is designed for graduate students and junior faculty in history, political science, law, and related disciplines. Although the Institute cannot offer academic credit directly for the seminar, students may be able to earn graduate credit through their home departments by completing an independent research project in conjunction with the seminar. There is no tuition or other charge for this seminar, though participants will be expected to acquire the assigned books on their own. Modest assistance with travel expenses from outside the New York metropolitan area will be available. Space is limited, so applicants should send a copy of their c.v. and a short statement on how this seminar will be useful to them in their research, teaching, or professional development. Materials will be accepted only by e-mail at MMarcus@nyhistory.org until September 1, 2011. Successful applicants will be notified soon thereafter. For further information, please contact Maeva Marcus at (202) 994-6562 or send an email to MMarcus@nyhistory.org. Further information is available at https:// www.nyhistory.org/ich/events.htm.

\section{Coming in the NEXT ISSUE}

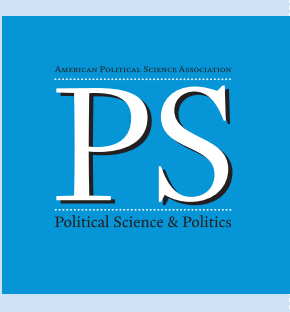

\section{SYMPOSIUM}

A Cultural Theory of Politics

Brendan Swedlow, guest editor

\section{FEATURES}

Are Financial or Moral Scandals Worse? It Depends

Conor M. Dowling, David Doherty, and Michael G. Miller

Understanding the Rise of Talk Radio Jeffrey M. Berry and Sarah Sobieraj

The Evolution of the Core of Post9/11 American Muslim Political Identity: Race and Religion in the Political Problematization of the American Muslim

Iqbal Akhtar

\section{THE PROFESSION}

The Modal Number of Citations to Political Science Articles Is Greater than Zero: Accounting for Citations in Articles and Books

David J. Samuels

Getting on the Board: The Presence of Women in Political Science Journal Editorial Positions

Laura Anne van Assendelft, Mary Stegmaier, and Barbara Palmer

\section{THE TEACHER}

Peer Evaluation in the Political Science Classroom Kimberly Weir

Preaching What We Practice: Bringing Scope and Methods "Back In"

Miguel Centellas

Teaching Process Tracing David Collier 